\title{
Aqua Ecotourism as Conservatory Mega Tool for Depensatory Fish Germplasm and Employment Generation
}

\author{
Anurag Protim Das*and Shyama Prasad Biswas \\ Department of Life Sciences, Dibrugarh University, India
}

Submission: March 12, 2018; Published: October 24, 2018

Corresponding author: Research Scholar,Department of Life Sciences, School of Science and Engineering,Dibrugarh University, 786004, India, Email: anuragprotim.99@gmail.com

\begin{abstract}
This study was carried out in Bogibeel, a stretch of river Brahmaputra from January 2015 to December 2016. A total, 40 species belonging to 16 families have been recorded from six different fish landing zone during the study period. It has been found that the fish diversity of these hotspots faces serious threats which would lead to a catastrophic loss of our biodiversity. In this work an attempt has been done to inventorize the fish community dwelling in the wetland, analysis of the anthropogenic threats and the prospect of aqua ecotourism is a mega conservatory tool to maintain ecological integrity of these aqua landscapes as well as the dwindling fish fauna.
\end{abstract}

Keywords: Ornamental fish;Bogibeel; Biodiversity; Conservation status;Aqua ecotourism

\section{Overview}

Recent assessments depicts that conservation of freshwater ecosystems has been in focus [1,2] since along with their terrestrial counterparts the aquatic ecosystems are increasing harnessed for providing renewable resources along with poor planning. With increasing change in global climate coupled with anthropogenic activities has drastically affected aquatic ecology as well as the fish community dwelling therein and wetlands are no exceptions to it. Evaluations suggest that worldwide $20 \%$ of all freshwater fish species are extinct, endangered or vulnerable [3].

Ecotourism is an emerging arena and aqua ecotourism is a much recent and debatable term. Study suggests that ecotourism achieved the attributes of generating economic benefits to that local mass as well conservation of nature. Aquarium fish keeping has evolved as an indispensible part of interior decoration in the 21 st century. In the work, an attempt has been made to prioritize among the fishes of this region the potential ornamental fishes along with their endemic status and status of threat and prospect of aqua ecotourism and recreational fisheries as conservatory mega tool.

\section{Materials and Methods}

Study area: Bogibeel (Coordination: 27.41/23// N, 94.75/65// E), a permanent stretch of river Brahmaputra and adjoining wetland. It has a meso-thermal climate. The temperature ranges between $10.6^{\circ} \mathrm{C}$ to $32^{\circ} \mathrm{C}$.

Sampling:Continuous monitoring and sampling is done so that rare indigenous fishes in different seasons are not missed for a period of one year from June 2015 to July, 2016. Fishes are collected randomly to cover all possible habitat types and identified and classified of following Talwar \& Jhingran [4].

\section{Results and Discussion}

During the investigation 40 species belonging to 17 families have been recorded from the six different fish landing zones. Emergence of high number exotic species like Ctenopharyngodon idella, Cyprinus carpio, and Hypophthalmichthys molitrix may be threat for indigenous species in near future. Out of 40 species following species Chitala chitala,Anabas testudineus, Channa marulius, Channa striatus,Mystus cavasius, Mystus tengara, Sperata aor, Clarias magur, Heteropneustes fossilis, Ompok bimaculatus, Ompok pabda, Ompok pabo and Monopterus cuchia have high market value as food fish. During the study it was observed that highly market demanded fishes like Chitala chitala, Ompok bimaculatus, Ompok pabda and Ompok pabo have coming into IUCN 2014.3Near threatened category. Due to this reason; these four species may be totally extinct from this wetland in near future. And species like Lepidocephalichthys guntea, Acanthocobitis botia, Mystus Cavasius, Chanda nama, 
Trichogaster fasciata, Trichogaster lalia, Xenentodon cancila, Esomus dandricus, Barilius barila, Nandus nandus, Channa aurantimaculata, Macrognathus pancalus, Badis badis, Badis badis havehigh ornamental value around the globe. And it should also be accounted that some of species Sperata aor, Badis badis, Macrognathus pancalus and Ompok pabda were found to be very rare during investigation and therefore it is necessary to conserve those species in the studied wetland[5,6].

\section{Aqua ecotourism as conservatory tool}

Aqua ecotourism is a much recent arena which amalgamates conservation along with employment generation. The money generating attributes will be from entry fees, angle hiring and bait, the restaurants as well as artificial breeding which have manifold advantages like conservation state can be achieved and helps in employment generation. Moreover, unauthorized fishing as well as other detrimental activities will be banned.

\section{References}

1. Olsen D, Dinerstein E, Canevari P, Davidson I, Castro G, et al. (1998) Freshwater biodiversity of Latin America and the Caribbean: A conservation assessment. Biodiversity Support Program, Washington DC, USA

2. Pringle CM, Scatena FN, Paaby-Hansen P, Nunez-Ferrera M (2000) River conservation in Latin America and the Caribbean. In: Boon PJ, Davies BR, Petts GE (Eds.), Global perspectives on River conservation: Science, policy and practice. J Wiley \& Sons, London, pp. 41-77.

3. Maclean RH, Jones RW (1995) Aquatic Biodiversity Conservation: a review of current issues and efforts. ON SIFR, Ottawa, Canada.

4. Talwar PK, Jhingran AG (1991) Inland Fishes of India and Adjacent Countries. Volume 1 \& 2. Oxford and IBH Publishing, New Delhi, Bombay, Calcutta, India.

5. Das AP, Biswas SP (2016) Carotenoids and Pigmentation in Ornamental Fish. J Aquac Mar Biol 4(4): 00093.

6. Ehrlich PR, Wilson EO (1991) Biodiversity studies: science and policy. Science 253(5021): 758-762.
Your next submission with Juniper Publishers will reach you the below assets

- Quality Editorial service

- Swift Peer Review

- Reprints availability

- E-prints Service

- Manuscript Podcast for convenient understanding

- Global attainment for your research

- Manuscript accessibility in different formats

( Pdf, E-pub, Full Text, Audio)

- Unceasing customer service

Track the below URL for one-step submission https://juniperpublishers.com/online-submission.php 